\title{
Assessment of the quality of staff competence: method and application experience
}

\author{
Anna Minnullin ${ }^{1,}$, Ruslan Minnullin ${ }^{1}$, Anna Kopytova ${ }^{1}$ and $S$. Dorofeev ${ }^{2}$ \\ ${ }^{1}$ Industrial University of Tyumen, Volodarskogo str. 38, Tyumen, Russia \\ ${ }^{2}$ Samara State Technical University, Molodogvardeyskaya street, 244, Samara, Russia
}

\begin{abstract}
The method for assessing the quality of training of energy company personnel consists in identifying criteria for assessing the quality of training energy and industrial equipment sales manager, ranking these criteria according to their importance, and determining the weights of these criteria, which will allow separating general and professional criteria of personnel for understanding the importance of basic education and subsequent experience. Approbation of the results obtained on the basis of a multi-criteria assessment allows heads of companies to attract managers with a higher professional level of training.
\end{abstract}

\section{Introduction}

The accelerated pace of development of the Russian energy industry has made changes in the composition and structure of personnel: the number of specialists employed in the field of management of assets, costs, projects, and finance has increased, the need for lawyers, pricing specialists, and traders has increased.

So, the main features of the composition and structure of the personnel of energy companies include $[1,2]$ :

- energy is a non-labor-intensive industry due to the high level of automation of production processes;

- a high proportion of personnel with secondary and higher education;

- ability of the operating personnel of energy companies to work according to the dispatcher's commands;

- stress resistance in the team;

- implementation of investment programs and commissioning of new generating capacities and network facilities increase the number of operating personnel;

- creation of independent repair companies competing with each other reduces the number of repair personnel.

Today, in addition to the demand for engineering personnel in energy companies, the demand for sales personnel with the skills to sell energy resources and industrial equipment in the energy sector has increased [3].

The modern scheme of training an energy and industrial equipment sales manager is based on two components:

\footnotetext{
${ }^{*}$ Corresponding author: minnullinaay@yandex.ru
} 
- basic education - fundamental knowledge in the field of economics and production/industrial management, after graduation - a state diploma;

- training - focused on obtaining professional knowledge, skills and abilities to work in a certain market (industry), after graduation - an international or state certificate. [4-6]

The task of training is to achieve a certain level of qualification for a specialist to perform a certain activity that meets the current and future needs of the company in order to achieve its strategic goals. Since the quality of sales of industrial equipment directly depends on the professionalism of personnel employed in this area, their competencies and skills must meet certain requirements.

The practice of studying the assessment of the quality of education in Russian and foreign universities allows concluding that there are two approaches to assessing the quality of education. The first approach uses ensuring the needs of students in an objective assessment of the quality of their education, the second - with the technology used for assessing students $[1,6,7]$.

In the first case, the criterion for the quality of education is the level of self-realization of the student in professional activity, i.e. increasing the student's competence in solving professional problems. In the second approach, the basic criteria for the quality of education are external indicators: academic performance, organization of the educational process, the number of scientific publications, etc.

The developed methodology for assessing the quality of training of energy and industrial equipment sales managers uses both considered approaches and is based on the placement and provision of information (primarily to the future manager) on the connection of training with the main professional tasks of the relevant field of activity, as well as information on the content and forms of self-training, on organization of the educational process, etc. [8].

\section{Materials and methods}

The main criteria for assessing the quality of training of an energy and industrial equipment sales manager in the field of energy are:

- $\quad$ skills of active sales of industrial equipment;

- $\quad$ experience/work experience in the field of sales;

- $\quad$ higher education in the field of management;

- $\quad$ experience/work experience in the field of management (economics, finance, etc.);

- $\quad$ experience/work experience in the field of energy;

- $\quad$ certificates confirming the completion of courses in sales, economics, etc.;

- $\quad$ experience in developing commercial proposals for large projects;

- $\quad$ recommendations from specialists;

- $\quad$ presence of ideas or knowledge in industries related to management, energy;

- $\quad$ ability to apply communication skills in the field of sales;

- $\quad$ flexibility of thinking, vision of problems, intuition. [9,10]

- Having singled out the criteria for assessing the quality of the training of an energy and industrial equipment sales manager, let's proceed to ranking these criteria according to their significance and determining the weights of these criteria (Table 1).

- It should be noted that the criteria are divided into two categories: general criteria and sales criteria. This will allow the separation of general and professional criteria for managers to understand the importance of basic education and subsequent work experience. 
Table 1. The results of ranking the criteria for assessing the quality of training of an energy and industrial equipment sales manager.

\begin{tabular}{|l|c|c|c|}
\hline \multicolumn{1}{|c|}{ Criteria } & Expert 1 & Expert 2 & Expert 3 \\
\hline 1. General criteria & \multicolumn{4}{|l|}{} \\
\hline Higher education in the field of management/energy & 3 & 5.5 & 6 \\
\hline $\begin{array}{l}\text { Experience/work experience in the field of } \\
\text { management (economics, finance, etc.) and energy }\end{array}$ & 5 & 5 & 5 \\
\hline Recommendations from specialists & 4.7 & 3.8 & 9 \\
\hline Presence of ideas or knowledge in related industries & 2.5 & 4 & 4 \\
\hline Flexibility of thinking, vision of problems, intuition & 7.5 & 9 & 7.8 \\
\hline 2. Criteria for the sale of energy resources and industrial equipment & & \\
\hline Skills of selling energy and/or industrial equipment & 8.5 & 10 & 7.5 \\
\hline Experience/work experience in the field of sales & 6.9 & 6.5 & 9 \\
\hline $\begin{array}{l}\text { Experience in developing commercial proposals for } \\
\text { large projects }\end{array}$ & 10 & 7.5 & 8 \\
\hline $\begin{array}{l}\text { Certificates confirming the completion of specialized } \\
\text { courses }\end{array}$ & 3.9 & 2.2 & 2 \\
\hline Ability to apply sales communication skills & 6 & 8 & 7.3 \\
\hline
\end{tabular}

To do this, the method of expert assessments will be used, namely the rank method. Let there be m experts: $E_{1}, E_{2}, \ldots, E_{m}$ and $\mathrm{n}$ goals, criteria or characteristics: $Z_{1}, Z_{2}, \ldots, Z_{n}$. Each expert evaluates goals using a 10-point scale, and the assessments can be both whole and fractional. Under these conditions, the target weights are determined as follows: [11-13]

1. Compilation of a matrix of expert assessments (table 2).

Table 2. Matrix of expert assessments.

\begin{tabular}{|c|c|c|c|c|}
\hline$Z_{i} E_{j}$ & $Z_{1}$ & $Z_{2}$ & $\ldots$ & $Z_{n}$ \\
\hline$E_{1}$ & $P_{11}$ & $P_{12}$ & $\ldots$ & $P_{1 n}$ \\
\hline$E_{2}$ & $P_{21}$ & $P_{22}$ & $\ldots$ & $P_{2 n}$ \\
\hline$\ldots$ & $\ldots$ & $\ldots$ & $\ldots$ & $\ldots$ \\
\hline$E_{m}$ & $P_{m 1}$ & $P_{m 2}$ & $\ldots$ & $P_{m n}$ \\
\hline
\end{tabular}

$$
0 \leq p_{i j} \leq 10(j=\overline{1, m} ; i=\overline{1, n})
$$

2. Compilation of a matrix of normalized estimates:

$$
R_{i j}=\frac{p_{i j}}{\sum_{i=1}^{n} p_{i j}} j=\overline{1, m} ; i=\overline{1, n}
$$

Calculation of the desired weights of goals, criteria or characteristics:

$$
R_{i}=\frac{\sum_{j=1}^{m} R_{i j}}{\sum_{j=1}^{m} \sum_{i=1}^{n} R_{i j}}, i=\overline{1, n} ; \sum_{i=1}^{n} R_{i}=1
$$

To determine the weight of each criterion, it is necessary to use formula (1) to compile a matrix of normalized estimates and formula (2) (table 3). According to the results of calculations, the most significant criteria in assessing the quality of training of an energy and industrial equipment sales manager can be seen. 
Table 3. Normalized estimates and weights of criteria for assessing the quality of training of an energy and industrial equipment sales manager.

\begin{tabular}{|c|c|c|c|c|}
\hline \multirow[t]{2}{*}{ Criteria } & \multicolumn{3}{|c|}{$\begin{array}{l}\text { Matrix of normalized expert } \\
\text { assessments }\end{array}$} & \multirow[t]{2}{*}{$\begin{array}{l}\text { Criterion } \\
\text { weight }\end{array}$} \\
\hline & $E_{1}$ & $E_{2}$ & $E_{3}$ & \\
\hline \multicolumn{5}{|l|}{ 1. General criteria } \\
\hline $\begin{array}{l}\text { Higher education in the field of } \\
\text { management/energy }\end{array}$ & 0.0517 & 0.0894 & 0.0915 & 0.077 \\
\hline $\begin{array}{l}\text { Experience/work experience in the field of } \\
\text { management (economics, finance, etc.) and } \\
\text { energy }\end{array}$ & 0.0862 & 0.0813 & 0.0762 & 0.121 \\
\hline Recommendations from specialists & 0.0810 & 0.0618 & 0.1372 & 0.093 \\
\hline $\begin{array}{l}\text { Presence of ideas or knowledge in related } \\
\text { industries }\end{array}$ & 0.0431 & 0.0650 & 0.0610 & 0.056 \\
\hline $\begin{array}{l}\text { Flexibility of thinking, vision of problems, } \\
\text { intuition }\end{array}$ & 0.1293 & 0.1463 & 0.1189 & 0.132 \\
\hline \multicolumn{5}{|c|}{ 2. Criteria for the sale of energy resources and industrial equipment } \\
\hline $\begin{array}{l}\text { Skills of selling energy and/or industrial } \\
\text { equipment }\end{array}$ & 0.1466 & 0.1626 & 0.1143 & 0.141 \\
\hline Experience/work experience in the field of sales & 0.1190 & 0.1057 & 0.1372 & 0.081 \\
\hline $\begin{array}{l}\text { Experience in developing commercial proposals } \\
\text { for large projects }\end{array}$ & 0.1724 & 0.1220 & 0.1220 & 0.139 \\
\hline Ability to apply sales communication skills & 0.1034 & 0.1301 & 0.1113 & 0.115 \\
\hline $\begin{array}{l}\text { Certificates confirming the completion of } \\
\text { specialized courses }\end{array}$ & 0.0672 & 0.0358 & 0.0305 & 0.045 \\
\hline
\end{tabular}

Summing up the criteria weights, the general criteria have a total weight of 0.4794 , and the sales criteria have a weight of 0.5206 . Thus, there is no significant preponderance of the sum of some criteria over others, which indicates the importance of the basic training of a manager in a university when mastering general cultural and professional competencies.

\section{Results}

To confirm the practical applicability, let's test the results obtained. Suppose there are 3 applicants for the position of energy and industrial equipment sales manager. The expert assessed the quality of their training based on the selected criteria using the method of multi-criteria assessment. The essence of the multicriteria assessment method is as follows: the table contains a list of assessment criteria. A rating scale is chosen, in this case, a 10point rating scale was used (from 1 to 10: the higher the score, the more highly the expert evaluates the quality of the applicant's training). If criteria weights are specified, then the assessment of the quality of the applicant's training for each criterion will be equal to the product of the expert's assessment by the weight of this criterion. The final score of each applicant will be equal to the sum of such products. The results of the expert's assessments without taking into account the weights of the criteria are presented in Table 4. 
Table 4. Assessments of the quality of training applicants for the position of energy and industrial equipment sales manager.

\begin{tabular}{|l|c|c|c|}
\hline \multirow{2}{*}{ Criteria } & \multicolumn{3}{c|}{ Point assessment of the quality of training of } \\
applicants
\end{tabular}

Table 5. Assessments of the quality of training of 3 applicants for the position of energy and industrial equipment sales manager, taking into account the weights of the criteria.

\begin{tabular}{|c|c|c|c|c|c|}
\hline \multirow[t]{2}{*}{ Criteria } & \multirow[t]{2}{*}{$\begin{array}{l}\text { Criterion } \\
\text { symbol }\end{array}$} & \multirow{2}{*}{$\begin{array}{l}\text { Criterion } \\
\text { weight }\end{array}$} & \multicolumn{3}{|c|}{$\begin{array}{l}\text { Assessment of the quality of training of } \\
\text { applicants, taking into account the } \\
\text { weights of the criteria }\end{array}$} \\
\hline & & & Applicant 1 & Applicant 2 & $\begin{array}{c}\text { Applicant } \\
3\end{array}$ \\
\hline $\begin{array}{l}\text { Higher education in the field of } \\
\text { management/energy }\end{array}$ & $Z_{1}$ & 0.077 & 0.6203 & 0.4652 & 0.6823 \\
\hline $\begin{array}{l}\text { Experience/work experience in the } \\
\text { field of management (economics, } \\
\text { finance, etc.) and energy }\end{array}$ & $Z_{2}$ & 0.121 & 0.3619 & 0.8443 & 0.6875 \\
\hline Recommendations from specialists & $Z_{3}$ & 0.093 & 0.0933 & 0.0933 & 0.6440 \\
\hline $\begin{array}{l}\text { Presence of ideas or knowledge in } \\
\text { related industries }\end{array}$ & $Z_{4}$ & 0.056 & 0.2819 & 0.1127 & 0.5017 \\
\hline $\begin{array}{l}\text { Flexibility of thinking, vision of } \\
\text { problems, intuition }\end{array}$ & $Z_{5}$ & 0.132 & 0.9206 & 0.9206 & 1.0127 \\
\hline $\begin{array}{l}\text { Skills of selling energy and/or } \\
\text { industrial equipment }\end{array}$ & $Z_{6}$ & 0.141 & 0.9881 & 0.9881 & 1.1011 \\
\hline $\begin{array}{l}\text { Experience/work experience in the } \\
\text { field of sales }\end{array}$ & $Z_{7}$ & 0.081 & 0.4062 & 0.0812 & 0.2843 \\
\hline $\begin{array}{l}\text { Experience in developing } \\
\text { commercial proposals for large } \\
\text { projects }\end{array}$ & $Z_{8}$ & 0.139 & 0.4163 & 0.8326 & 1.0963 \\
\hline $\begin{array}{l}\text { Ability to apply sales } \\
\text { communication skills }\end{array}$ & $Z_{9}$ & 0.115 & 1.0344 & 0.2299 & 1.1034 \\
\hline $\begin{array}{l}\text { Certificates confirming the } \\
\text { completion of specialized courses }\end{array}$ & $Z_{10}$ & 0.045 & 0.3115 & 0.0445 & 0.1068 \\
\hline \multicolumn{3}{|l|}{ Total score } & 5.4346 & 4.6126 & 7.2202 \\
\hline
\end{tabular}

Knowing the weight of each criterion and the points given by the expert, it is possible to calculate and compare the results of applicants for the position of energy and industrial 
equipment sales manager. The results of expert assessments of the quality of training of managers, taking into account the weights of the criteria, are presented in Table 5.

Table 5 shows that Applicant 3 has the highest total score out of three applicants for the position of energy and industrial equipment sales manager. This means that the quality or level of his training was rated higher than the other two managers, and, most likely, he will be hired for the analyzed position. The reasons for this result lie on the surface: it was Applicant 3 who scored the maximum points on 4 out of 5 main criteria for assessing the quality of training of an energy and industrial equipment sales manager.

\section{Discussions}

Thus, despite the fact that the most significant criteria for training an energy and industrial equipment sales manager are not directly related to the university (skills in active sales of industrial equipment; experience in developing commercial proposals for large projects; experience/work experience in sales), the development of these criteria is largely determined by the level of preparation of the student at the university, his involvement in both the educational and scientific process (speaking at conferences, preparing presentations, etc.).

This method will allow the heads of companies to attract energy and industrial equipment sales managers with higher criteria, which will ultimately affect the professionalism of managers and the economic indicators of the company itself in the process of development and further functioning.

\section{Recommendations}

The materials of the paper are important for the heads of energy companies and other related industries when substantiating management decisions to improve the organizational structure and personnel management system, as well as when developing internal documentation.

\section{References}

1. Y. Arsenyev, Innovations in the economy of electric power industry: production, distribution, mergers and acquisitions, optimization 300 (2014)

2. Y. Kudryavtseva, Current requirements for energy management 2(48),18-20 (2011)

3. G. Marchenko, Proceedings of higher educational institutions, Energy issues 9-10, 135140 (2012)

4. I. Nemirovsky, Energy: economy, technology, ecology 2(36), 33-38 (2014)

5. A. Minnullina, IOP Conference Series: Earth and Environmental Science 90, 012089 (2017) doi:10.1088/1755-1315/90/1/012089

6. S. Hohlyavin, Energy audit 4(20), 26-31 (2011)

7. R. Farkhutdinov, Proceedings of higher educational institutions. Energy issues 5-6, 92 (2014)

8. N. Zotkina, M. Gusarova, A. Kopytova, Advances in Intelligent Systems and Computing 692, 1204-1213 (2018) DOI: 10.1007/978-3-319-70987-1_129

9. A.V. Kopytova, MATEC Web of Conferences 106, 08056 (2017) DOI: 10.1051/matecconf/201710608056

10. A.V. Kopytova, Exchange of intellectual property 3 (XIV), 31-37 (2015) 
11. A. Minnullina, MATEC Web of conference 106, 08067 (2017) doi: 10.1051/matecconf/201710608067

12. A.S. Gorshkov, N.I. Vatin, P.P. Rymkevich. Construction of Unique Buildings and Structures. 2020. 89(4). Pp. 8902-8902. DOI:10.18720/CUBS.89.2.

13. A. Minnullina, R. Abdrazakov, Advances in Intelligent Systems and Computing 692, 1224-1233 (2018) doi: 10.1007/978-3-319-70987-1_131

14. T. Gorokhova, et al. E3S Web of Conferences 135, 04069 (2019) doi:10.1051/e3sconf/201913504069 